\title{
New records of the rare gastropods Erato voluta and Simnia patula, and first record of Simnia hiscocki from Norway
}

\author{
Jon-Arne Sneli' and Torkild Bakken ${ }^{2}$
}

Sneli J-A, and Bakken T. 2017. New records of the rare gastropods Erato voluta and Simnia patula, and first record of Simnia hiscocki from Norway. Fauna norvegica 37: 20-24.

New records of rare gastropod species are reported. A live specimen of Erato voluta (Gastropoda: Triviidae), a species considered to have a far more southern distribution, has been found from outside the Trondheimsfjord. The specimen was sampled from a gravel habitat with Modiolus shells at 49-94 $\mathrm{m}$ depth, and was found among compound ascidians, its typical food resource. Live specimens of Simnia patula (Caenogastropoda: Ovulidae) have during the later years repeatedly been observed on locations on the coast of central Norway, which is documented by in situ observations. In Egersund on the southwest coast of Norway a specimen of Simnia hiscocki was in March 2017 observed for the first time from Norwegian waters, a species earlier only found on the south-west coast of England. Also this was documented by pictures and in situ observations. The specimen of Simnia hiscocki was for the first time found on the octocoral Swiftia pallida.

doi: 10.5324/fn.v37i0.2160. Received: 2016-12-01. Accepted: 2017-09-20. Published online: 2017-10-26. ISSN: $1891-5396$ (electronic).

Keywords: Gastropoda, Ovulidae, Triviidae, Erato voluta, Simnia hiscocki, Simnia patula, Xandarovula patula, distribution, morphology.

1. NTNU Norwegian University of Science and Technology, Department of Biology, NO-7491 Trondheim, Norway.

2. NTNU Norwegian University of Science and Technology, University Museum, NO-7491 Trondheim, Norway.

Corresponding author: Jon-Arne Sneli

E-mail: jon.sneli@ntnu.no

\section{INTRODUCTION}

After 1990, the climatic conditions in the Norwegian coastal waters have changed as a significant temperature increase has occurred in the Atlantic water along the Norwegian coast (Aure 2016). In Sognesjøen in the opening of the Sognefjord the decadal mean temperature at $200 \mathrm{~m}$ depth from 1940 to 1990 varied between 7.6 and $7.9^{\circ} \mathrm{C}$. Between 2000 and 2010 the mean temperature has increased to about $0.7^{\circ} \mathrm{C}$ above the $1940-1989$ long-term average (Albertsen and Asplin 2017). After 2010 the mean temperature in the Atlantic water in the southern coastal areas are reduced by about $0.2^{\circ} \mathrm{C}$ (Albertsen and Asplin 2017). During the entire 2015 and 2016, temperatures in both the surface layer and deep water along the entire Norwegian coast were above normal (Aure 2016, Albertsen and Asplin 2017).

From 1997 to 2011, more than 100 new marine bottom dwelling species from more temperate waters have established themselves in Norwegian waters. At least two thirds of these 
have entered our seas from Scotland and Shetland, and the rest have arrived from the coasts of Sweden and Denmark (Brattegard 2011).

Gastropods are among the better-known groups of benthic organisms in Norwegian coastal waters (Høisæter 2009). Nevertheless, new records of relatively large grown species may be discovered, even in areas that are well explored. Representatives of species with a distribution confined to the south and western parts of Great Britain have recently been recorded in central and southwestern Norway: Erato voluta (Montagu, 1803), Simnia (= Xandarovula) patula (Pennant, 1777), and Simnia hiscocki (Lorenz \& Melaun, 2011).

In 1973, Cate designated Simnia patula as the type specimen of the new genus Xandarovula Cate, 1973. There has been much confusion about this genus name, which was reviewed in Høisæter et al. (2011), where the name Xandarovula was used when describing new records of this species in Scandinavian waters. However, Gofas and Bouchet (2015) in the World Register of Marine Species (WoRMS) states that the taxonomic situation is unsettled and all species involved are provisionally (as of 05/2010) listed as accepted under Simnia.

\section{MATERIAL AND METHODS}

\section{Material}

Specimens examined and reported where obtained from dredging and SCUBA diving. Collected specimens reported as new are deposited in the collections at the Norwegian University of Science and Technology, NTNU University Museum (NTNU-VM). Earlier records referred to in the text are deposited in the collections at the Swedish Museum of Natural History (SMNH).

\section{Localities}

Erato voluta was found 23 June 2015 at Mølnbukt, Agdenes (63 $37.794 \mathrm{~N} 09^{\circ} 38.741 \mathrm{E}$ ) (Figure 1) sampled with triangular dredge from 94-49 m depth.

Simnia patula were collected by under-water photographer Nils Aukan in January 2016 at Brattøy, Kristiansund (63 3.644N $7^{\circ} 41.44 \mathrm{E}$ ) during several dives in January and March 2016, at 21-32 m depth (Figure 1).

Simnia hiscocki was observed 14 of March 2017 at 32 $m$ depth by under-water photographer Erling Svensen at the northern end of the island Skarvøya at the southern approach to Egersund harbour on the southwest coast of Norway (Figure 1).

\section{RESULTS}

\section{Simnia patula}

The new records of Simnia patula were reported to the authors by under-water photographer Nils Aukan. He observed specimens at Brattøy, during several dives in January and

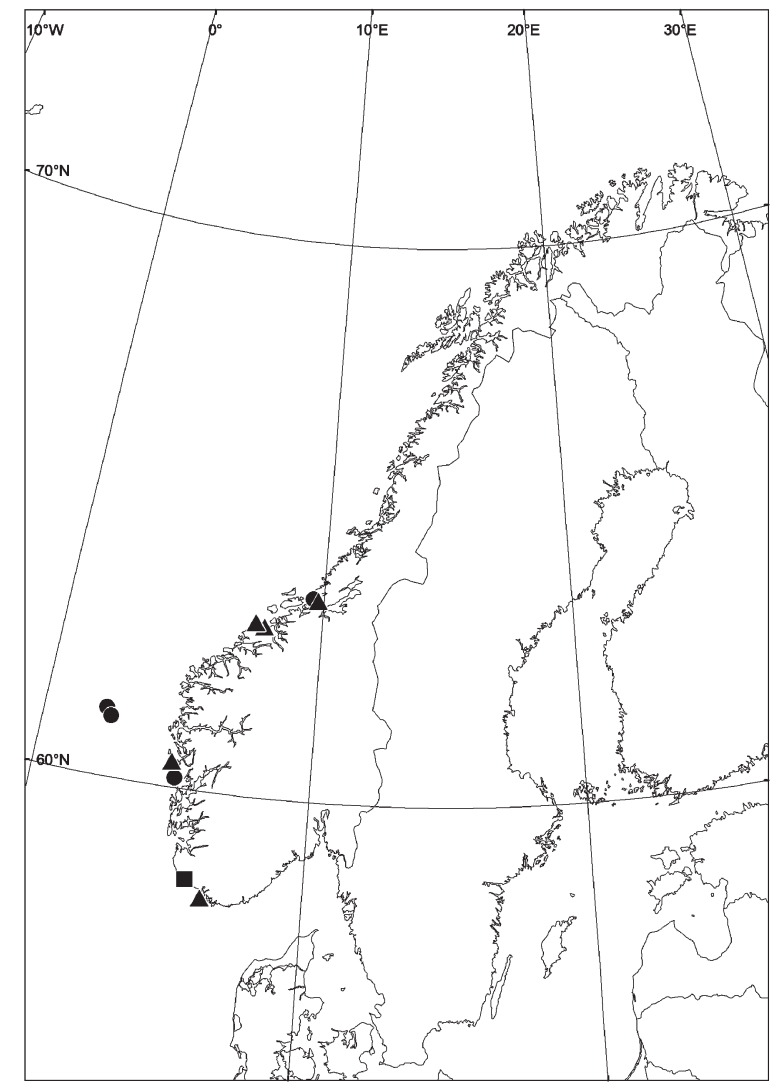

Figure I. Map of the Norwegian coast marked with known records of

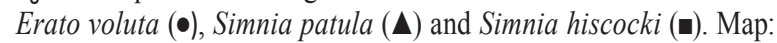
Marc Daverdin.

March 2016, at 21-32 m depth, feeding on Alcyonium digitatum (Figure 2). Aukan retrieved one specimen that is deposited in the collections at NTNU University Museum (NTNU-VM-72480). He has later observed the species at Averøya southwest of Kristansund (Figure 1). Shell length of the observed specimens were about $20 \mathrm{~mm}$.

In 2003 a specimen of Simnia patula was found and photographed by Espen Rekdal at Selva, Agdenes in the opening of the Trondheimsfjord. Further records of S. patula from an area near Bergen were found in 2010. Together with records from an area west of Smögen on the Swedish West coast in 2009, these were the first reliably reported finds of this species in Scandinavia (Høisæter et al. 2011).

Lorenz and Melaun (2011) also reported finds of the species at Lista lighthouse on the south coast of Norway (Figure 1).

These finds in Norwegian waters (Figure 1) greatly expand the northern limits of the distribution of Simnia patula.

\section{Erato voluta}

A live specimen of the egg cowrie Erato voluta was found 23 June 2015 at Agdenes in a gravely-sandy bottom with dead Modiolus modiolus shells. The live specimen of Erato voluta (Figure 3) was found associated with compound ascidians, its 


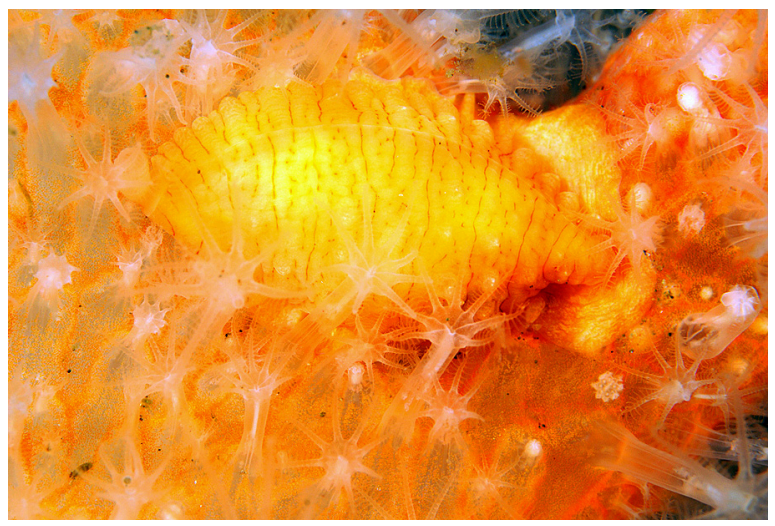

Figure 2. In situ photograph of Simnia patula feeding on Alcyonium digitatum at Brattøy, Kristiansund, Norway, photographed $30^{\text {th }}$ of March 2016. Photo: Nils Aukan.

typical food resource, in a species rich sample associated with this bottom type. The specimen is deposited in the collections at the NTNU University Museum (NTNU-VM-72481). It has not been possible to find additional specimens despite several later attempts dredging in the same location.

Erato voluta has a solid shell, nearly opaque and glossy (Figure 3). The spire is short so that the body whorl occupies most of the shell with its long, narrow aperture (Figure 3). When the animal is active, the shell is covered by mantle lobes (Fretter and Graham 1981). The species is up to $12 \mathrm{~mm}$ high and the body whorl occupies $80-85 \%$ of the shell height and with the aperture occupying $75-80 \%$ of the total shell height. The animal lives on hard bottoms at depths of 20 to $150 \mathrm{~m}$ where ascidian species as the compound species of Botryllus and Botrylloides, are thought to be their main food source (Fretter and Graham 1981). The sexes are separate and the male is easily recognized by an easily seen penis.

Erato voluta was earlier considered a British-Mediterranean species although Fretter (1951) reported finds from the Skagerrak coast of Norway but unfortunately without more information. The species has a depth distribution from 20 to $100 \mathrm{~m}$ off most shores of the British Isles except in the eastern waters of England between Humber and the Isle of Wight. It is rare in Northern Ireland and is with certainty only found in Galway Bay in Ireland (Seaward 1990). Since 1990, E. voluta has extended its distribution area northwards along the British coast with several records in the waters of the Orkneys and Shetland (Rowley 2008). It is not found on continental shores of the North Sea (Rowley 2008) and is not mentioned by Jensen and Knudsen (1995) from Danish waters.

\section{Simnia hiscocki}

Figure 3. Photographs of Erato voluta found at Agdenes, Norway in 2015. A, live specimen photographed in the field. B, preserved shell of the same specimen. Scale bar $=2 \mathrm{~mm}$. Photo: Torkild Bakken.
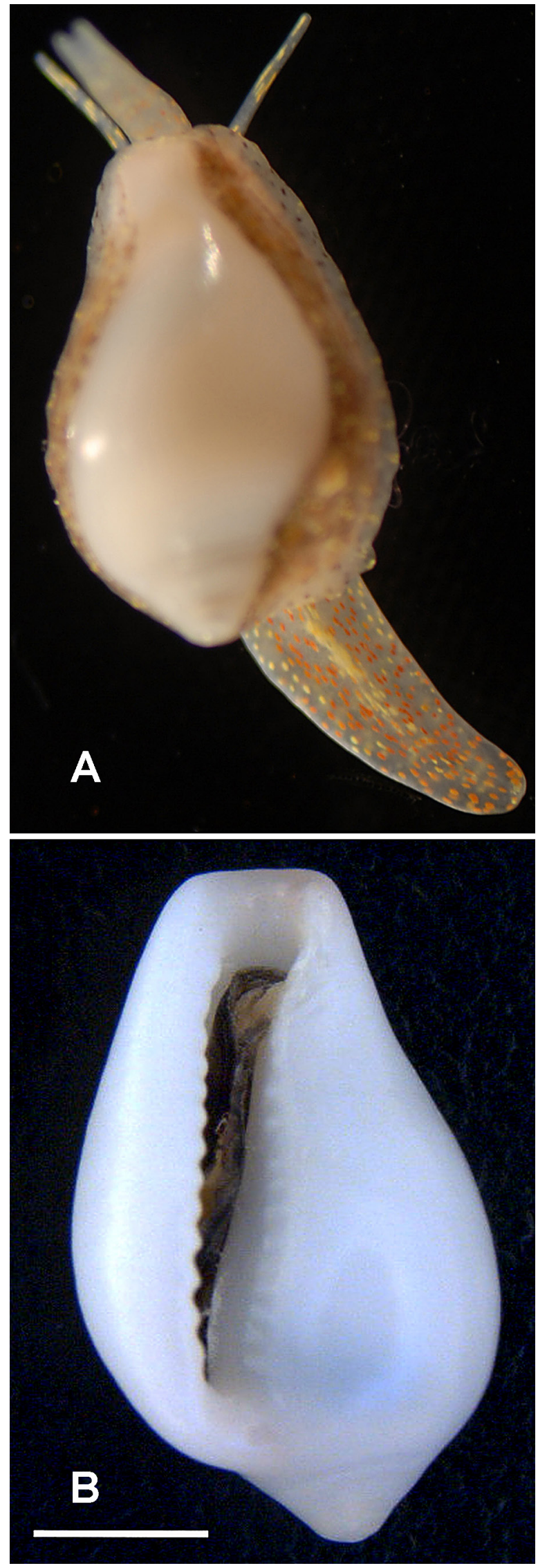
On the $14^{\text {th }}$ of March 2017, Erling Svensen observed a specimen of Simnia hiscocki at the approach to Egersund (Figure 1). Svensen found the specimen at $32 \mathrm{~m}$ depth and took a picture (Figure 4), which later has been confirmed to be $S$. hiscocki by Keith Hiscock. The specimen was found on the gorgonacean Swiftia pallida Madsen, 1970, a close relative of Eunicella verrucosa (Pallas, 1766), which the species up until now had been exclusively found on. Eunicella verrucosa is a southern species so far not recorded from Norwegian waters.

Simnia hiscocki was described as a new species based on 34 live-collected specimens from several collecting sites around Plymouth on the southwestern coast of England in 2011. Until now, the species has been found only at the type locality and only on its octocoral host Eunicella verrucosa (Lorenz and Melaun 2011). Simnia hiscocki is here reported from Norway for the first time.

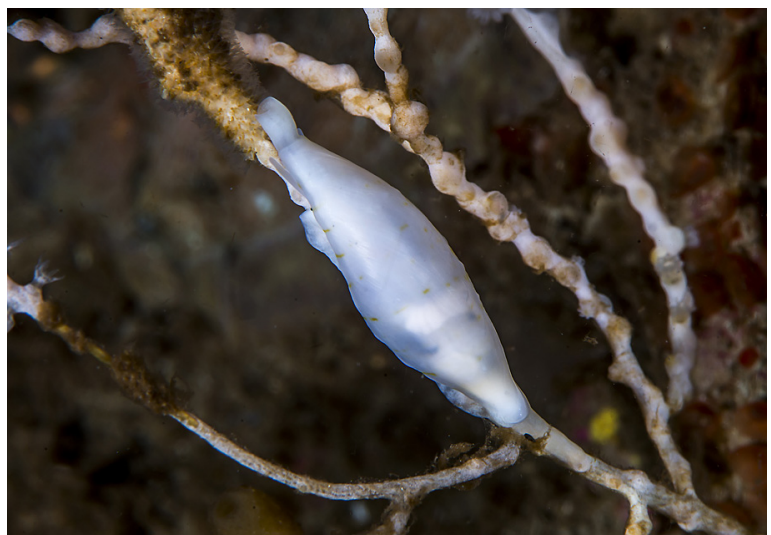

Figure 4. The specimen of Simnia hiscocki from Egersund harbour on the $14^{\text {th }}$ of March 2017. Photo: Erling Svensen.

\section{DISCUSSION}

The eggs of Erato voluta are unknown but after breeding, planktonic larvae are found in the water of Great Britain from April to November (Lebour 1933). As the species has become rather common in the Orkneys and Shetland it is natural to think that larvae may spread from this area by the North Atlantic drift through the Faroe-Shetland Trough and transported to the Norwegian west coast.

In 1969, Anders Warén (pers. comm.) found one live specimen of $E$. voluta on $110 \mathrm{~m}$ depth at the Korsfjord, south of Fiksneset in Sund, Hordaland (Figure 1). The specimen is stored at the Swedish Museum of Natural History (SMNH catalogue number 17251). The record from 1969 is repeated in Fretter and Graham (1981). Hubendick and Warén (1971) wrote that the species had to be found in the Skagerrak but not yet in Bohuslän on the Swedish west coast. In a later publication, they state that $E$. voluta is found at Grimstad on the Norwegian southeast coast (Hubendick and Warén 1975). So far, there is no documentation of this find in the literature, and The Swedish
Species Information Centre states no findings of the species at the Swedish west coast in their latest Red List (ArtDatabanken 2015).

In 1999, the consulting company Akvaplan-Niva sampled at the Gullfaks oil field in the North Sea and two live specimens of E. voluta were found at 130-140 m depth and identified by A. Warén (SNMH catalogue numbers 35552 and 41096). In addition, we are informed that in 2008 two shells of juvenile specimens of E. voluta were found at $189 \mathrm{~m}$ depth at the Kvitebjørn installations in The North Sea. Both the Gullfaks and the Kvitebjørn installations are situated (Figure 1) in the area of the North Sea were the main Atlantic water masses passes on its way to the Norwegian coast and specimens could well be transported as planktonic larvae from Shetland this way.

This is also a possible way for spreading of larvae of $S$. patula as the species has become rather common with many records in the waters of the Orkneys and Shetland (Rowley 2008) but not found on continental shores of the North Sea.

Simnia hiscocki is a recently described species and has probably been overlooked. It is so far only known from the octocoral species Eunicella verrucosa and Swiftia pallida, which is considered uncommon with a patchy distribution. A likely dispersal route is transportation with tidal currents passing across the southern North Sea and west of Denmark in the Jutland current to the Skagerrak coast of Norway (see Fig. 4 in Høisæter et al. 2011). But as the species is just recently described as new from Plymouth (2011) it is of course also possible that it has been overlooked elsewhere on the British coasts. Lebour (1932) found that 'Simnia' must have a long larval life and thus a transport of larvae from localities on the western side of the British Isles to join the North Atlantic drift at Shetland and then with different currents in the North Sea be transported to the Norwegian south coast is of course possible.

\section{ACKNOWLEDGMENTS}

We are grateful to under-water photographers Nils Aukan and Erling Svensen for their interest in marine fauna that leads to numerous questions on species and interesting records, and for allowing us to use of their excellent photographs. We thank Håvard Gullik Sørbø who made us aware of the unusual gastropod that showed up during sorting of samples during the field course in biology in 2015. We also thanks Sabine Stöhr and Anders Warén for information on earlier records of the species E. voluta, and Keith Hiscock is thanked for verifying the identification of Simnia hiscocki. We are grateful for comments from reviewers on an earlier version of this manuscript that contributed with valuable information. 


\section{REFERENCES}

ArtDatabanken 2015. Rödlistade arter i Sverige 2015. ArtDatabanken SLU, Uppsala.

Albertsen J., Asplin L. 2017. Kystklima. In Bakketeig I.E., Hauge M. og Kvamme C (red.). Havforskningsrapporten 2017. Fisken og havet, særnr. 1-2017: 6-8.

Aure J. 2016. Kystklima. Havforskningsrapporten 2016. Fisken og havet, særnummer 1-2016: 40-42.

Brattegard T. 2011. Endringer i norsk marin bunnfauna 1997 - 2010. Utredning for DN 2011 - 8. Direktoratet for naturforvaltning, $112 \mathrm{pp}$.

Cate CN. 1973. A systematic revision of the recent cypraeid family Ovulidae (Mollusca: Gastropoda). Veliger 15, Supplement I-IV: 1-116.

Fretter V. 1951. Some observations on the British cypraeids. Proceedings of the Malacological Society of London 29: 14-20.

Fretter V, Graham A. 1981. The Prosobranch Molluscs of Britain and Denmark. Part 6 (pp. 285-362) - Cerithiacea, Strombacea, Hipponicacaea etc. Journal of Molluscan Studies, Supplement 9: 285-362.

Høisæter T. 2009. Distribution of marine, benthic, shell bearing gastropods along the Norwegian coast. Fauna norvegica 28: 5-106. doi: 10.5324/fn.v28i0.563

Høisæter T, Sneli J-A, Schander C, Rapp H-T, Berggren M. 2011. Xandarovula patula (Gastropoda: Ovulidae) new to Scandinavia. Marine Biodiversity Records 4: 1-4. doi: 10.1017/ S1755267211000583

Hubendick B, Warén A. 1971. Småsnäckor från Svenska Västkusten 3. Släktena Cingula, Capulacmaea, Homalogyra, Caecum, Nassarius m. fl. Göteborgs Naturhistoriska Museum, Årstryck 1971: 43-49.

Hubendick B, Warén A. 1975. Småsnäckor vid Svenska västkusten 7. Acmaea, Gibbula, Calliostoma, Littorea m. fl. Göteborgs Naturhistoriska Museum, Årstryck 1975: 43.

Jensen KR, Knudsen J. 1995. Annotated checklist of recent marine molluscs of Danish waters. Jørgen Knudsen publisher, Zoological Museum, Copenhagen. 73 p.

Lebour, M.V. 1932. The larval stages of Simnia patula. Journal of the Marine Biological Association of the United Kingdom 18: 107-114.

Lebour MV. 1933. The larval stages of Erato voluta (Montagu). Journal of the Marine Biological Association of the UK 18: 485-90.

Lorenz F, Melaun C. 2011. A new species of Simnia from England (Caenogastropoda: Ovulidae). Molluscan Research 31(3): 167175.

Rowley S. 2008. Simnia patula. A gastropod. MarLIN The Marine Life Information network. http://www.marlin.ac.uk/ speciesinformation.php?speciesID $=4343$

Seaward DR. 1990 Distribution of the marine molluscs of northwest Europe. Nature Conservancy Council, Peterborough for Conchological Society of Great Britain \& Ireland. 114 pp.
Editorial responsibility: Anne Helene Solberg Tandberg.

This article is open-access and distributed under the terms of the Creative Commons Attribution 4.0 International license. This permits all non-commercial use, distribution, and reproduction in any medium, provided the original work is properly cited. (http://creativecommons.org/licenses/by/4.0/). 